\title{
Borehole Resistance and Heat Conduction Around Vertical Ground Heat Exchangers
}

\author{
Zoi Sagia*, Athina Stegou and Constantinos Rakopoulos \\ Thermal Engineering Department, School of Mechanical Engineering, National Technical University of Athens, 9 \\ Heroon Polytechniou St., Zografou Campus, 15780 Athens, Greece
}

\begin{abstract}
Borehole thermal resistance in Ground Heat Exchanger (GHE) installations is affected by several parameters such as geometrical attributes of heat exchanger in the borehole, pipes' characteristics and grout's thermal conductivity. A study is carried out to compare the values computed by Ground Loop Design (GLD) Software, GLD 2009, with three analytical solutions for U-shaped tubes. The analysis is focused on dimensionless ratios of borehole geometrical parameters (borehole diameter to outside pipe diameter and shank spacing to borehole diameter) and pipes according to Standard Dimension Ratio (SDR) and on eight common grouts. Finally, the effect of heat conduction in the borehole is examined by means of finite element analysis by Heat Transfer Module of COMSOL Multiphysics. A two-dimensional (2-D) steadystate simulation is done assuming working fluid temperatures for winter and summer conditions and typical Greek undisturbed ground temperature in a field of four ground vertical U-tube heat exchangers surrounded by infinite ground. The temperature profile is presented and the total conductive heat flux from the pipe to the borehole wall per meter of length of ground heat exchanger is computed for pipes SDR11 (the outside diameter of the pipe is 11 times the thickness of its wall), SDR9 and SDR17 for summer working conditions and three different configurations. It is attempted to reach to comparative results for borehole thermal resistance value through different types of analysis, having considered the major factors that affect it and giving trends for the influence of each factor to the magnitude of its value.
\end{abstract}

Keywords: Geothermal, Borehole, Borehole Thermal Resistance, Ground Heat Exchanger, Heat Conduction, Standard Dimension Ratio.

\section{INTRODUCTION}

Geothermal energy $[1,2]$ is conceived as a clean and cost effective form of energy with various applications for space heating and cooling. Ground Source Heat Pump (GSHP) systems, which are established to exploit the undisturbed ground temperature, consist of several parts with the Ground Heat Exchanger (GHE) to be the most important of them. GHE's major role is not only its contribution to the system's operation but also its contribution to the energy saving.

Several attempts [3, 4], which utilize analytical and numerical models, steady-state and transient analysis, onedimensional (1-D), two-dimensional (2-D) and threedimensional (3-D) simulation, have been done to model the operation and efficiency of GHE in a GSHP system. The use of different numerical techniques in engineering environmental applications is becoming more and more popular $[5,6]$. Analytical models for GHE utilize mainly two theories, line heat source $[7,8]$ and cylinder heat source theory $[9,10]$ to predict the heat exchange between the soil and the heat carrier fluid in the GHE. Numerical models [11] calculate finite differences to simulate the temperature distribution profile around the GHE. Steady-state analysis [12] is used to

*Address correspondence to this author at the Thermal Processes Laboratory, Thermal Engineering Department, School of Mechanical Engineering, National Technical University of Athens, 9 Heroon Polytechniou St., Zografou Campus, 15780 Athens, Greece; Tel.: +30 210 7723976;

Fax: +30 210 7723976; E-mail: zoisagia@mail.ntua.gr estimate average heat transfer rates between the circulating fluid and the ground for given working conditions whereas, transient simulation [13] calculates heat transfer rates taking into consideration the changeable working conditions of the GSHP system during a long working period. In the 1-D simulation [14] borehole is regarded as an infinite line source or sink of heat in an infinite medium, the soil, whereas in the 2-D simulation [15] calculations are performed in a cross-sectional area of GHE to the working fluid flow. These attempts are based on two significant observations. Firstly, the GHEs diameters are very small comparing with their lengths and secondly, the temperature of the ground can be assumed as constant under certain depth, what is called undisturbed ground temperature, ignoring that temperature increases $1-3{ }^{\circ} \mathrm{C}$ every $100 \mathrm{~m}$ of depth of the earth surface [16]. The 3-D simulation attempts to model the full geometry of GHE during its operation so as to achieve more precise results of heat transfer calculations but this is not always achievable.

A number of physical phenomena are taking place during the operation of GHE such as heat conduction, heat convection, working fluid flow, groundwater movement and others with minor significance to GSHP system efficient operation. The heat conduction between the soil and the heat carrier fluid in the GHE plays a major role in the operation of GSHP engineering applications, thus it is a common topic for researchers in the field of geothermal energy. The physical and thermodynamic properties of the circulating fluid, pipe material, filling material between the pipes and the ground, and 
the ground including the presence of groundwater, air gaps and living organisms, adding the kind of fluid's flow, pipe number and configuration and the presence of other heat sources or heat obstacles in a thermally effective distance consist the factors that affect GHE heat conduction.

In the present work, the heat conduction around vertical ground heat exchangers with U-shaped pipe configuration is examined. The pipes are placed in a drilled hole in the soil, borehole, and it is filled with a mixture of grout so as to ensure the stability of the formation, to fill any possible gaps created during the installation and to enhance the heat transfer rate between the working fluid and the ground (see Fig. (1)).

The objective of this study is to evaluate the influence of the factors which affect GHE heat conduction in the borehole by steady-state analytical simulations and a 2-D steady-state numerical one. Different set of factors are taking into account in order to calculate the thermal resistance that occurs between the heat carrier fluid and the infinite ground while emphasis is given on dimensionless ratios such as borehole diameter to outside pipe diameter, pipe shank spacing to borehole diameter and outside pipe diameter to pipe wall thickness. The different types of analysis attempt to reach to comparative results for borehole thermal resistance value without disregarding the major factors which affect it. In addition, the general trends which show the influence of each factor to the magnitude of borehole thermal resistance value are presented. These trends can be used as guidance to GHE installations.

\section{GHE MODEL DESCRIPTION}

\subsection{Geometrical Attributes}

The system is consisted of a single U-pipe heat exchanger encasing in a borehole as Fig. (1) depicts. Three configurations of GHE pipes are assumed which modify the centre-to-centre distance or in other words the shank spacings. These are: close together configuration in which the outer diameters of the pipes $d_{o}$ are in contact at the centre of the bore, average configuration in which each pipe is placed at an equal distance between the centre and the wall of the bore and along outer wall configuration in which the outer diameters of pipes touch the bore wall. The pipes have standard nominal diameter which is 1 in. or $25.4 \mathrm{~mm}$ and this stands for an outer diameter $d_{o}$ equals to $33.4 \mathrm{~mm}$. The internal pipe diameter $d_{i}$ varies according to Standard Dimension Ratio (SDR). This is the ratio of the pipe outer diameter $d_{o}$ to its wall thickness $s_{p}$ and is written as:

$S D R=\frac{d_{o}}{s_{p}}$

Table 1. Standard Dimension Ratios' characteristics [16, 18]

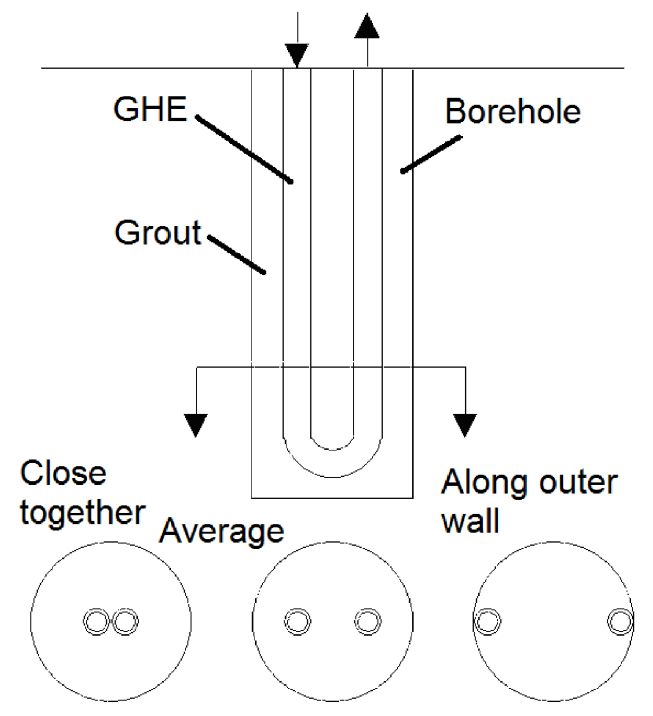

Fig. (1). Vertical Ground Heat Exchanger and Configurations.

The SDR is a common method of rating pressure piping for many plastic pipe manufacturers [17]. Plastic materials, especially High Density Polyethylene (HDPE), are widely used at geothermal piping systems as being durable materials with satisfactory thermal conductivity. Table 1 shows the SDR values used in the present study as well as the relevant internal pipe diameters [18] and their pressure ratings [16].

Although ground loops usually operate at 2-3 bar pressure, pipe materials of at least 6 bar are used [16]. In addition, these pressure ratings refer to $20{ }^{\circ} \mathrm{C}$ and fall as the operating pipe temperature increases.

The borehole diameter $d_{b}$ ranges from $90 \mathrm{~mm}$ to $190 \mathrm{~mm}$ with $20 \mathrm{~mm}$ step. This range is a common range of borehole diameters in GHE applications [16]. Eight widely-used grouts [18] with different thermal conductivities are tested (see Table 2).

\subsection{Analytical Correlations}

Three analytical solutions given from Shonder and Beck $[14,19], \mathrm{Gu}$ and O'Neal [20] and Remund [21], which estimate borehole thermal resistance, are compared with the values computed by Ground Loop Design (GLD) Software 2009. Shonder and Beck $[14,19]$ presented a 1-D heat conduction simulation for GHE. They modelled the U-tube pipes as a single pipe in the centre of the bore with an equivalent radius accounted for the same cross sectional area of heat exchange which had been presented by Bose [22]. The borehole thermal resistance $R_{b}$ was calculated by:

\begin{tabular}{|c|c|c|}
\hline SDR & Internal Diameter (mm) & Pressure Rating (bar) \\
\hline \hline SDR9 & 25.9 & 13.8 \\
\hline SDR11 & 27.4 & 11 \\
\hline SDR17 & 29.5 & 6.9 \\
\hline
\end{tabular}


$R_{b}=\frac{1}{2 \pi k_{g}} \ln \left(\frac{d_{b}}{d_{p} \sqrt{n}}\right)$

where $k_{g}$ is the thermal conductivity of grout and $\mathrm{n}$ is the number of pipes in the borehole (two pipes in the current work). This model utilizes the solution for the coaxial pipe. The thickness of the pipe wall has been replaced with a thin film which thermal resistance accounts for the pipe's thermal resistance and for the convective thermal resistance between the heat carrier fluid and the pipe. The heat conduction between the thin film, filling material and ground is calculated in the radial direction.

$\mathrm{Gu}$ and O'Neal [20] proposed another expression for the equivalent diameter of a vertical U-tube GHE. They performed a steady-state heat transfer simulation based on the cylindrical source model. It was assumed the concentricity of the borehole and one leg of the U-tube. The principle of superposition of multiple heat sources was applied. The equivalent diameter depends on the tube diameter and the leg spacing. The borehole thermal resistance $R_{b}$ was given by:

$R_{b}=\frac{1}{2 \pi k_{g}} \ln \left(\frac{d_{b}}{d_{p}} \sqrt{\frac{d_{p}}{s}}\right)$

Remund [21] presented Eq. (4) to evaluate borehole thermal resistance for the three configuration of GHE pipes mentioned above: close together, average and along outer wall.

$$
R_{b}=\frac{1}{\beta_{o}\left(\frac{d_{b}}{d_{p}}\right)^{\beta_{i}} k_{g}}
$$

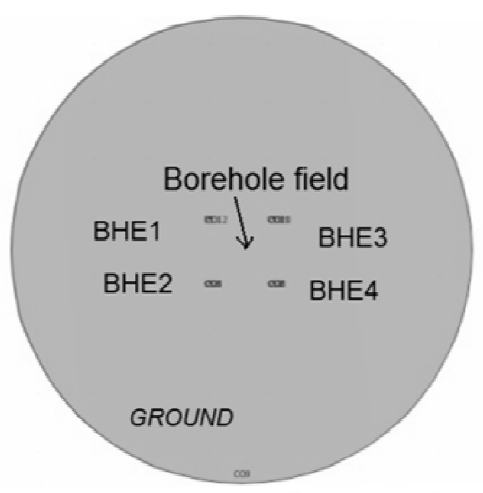

Fig. (2). Geometrical Mode of Numerical Simulation.

The coefficients $\beta_{o}$ and $\beta_{i}$ have been derived from experimental data, using different grouts and they are given on Table 3.

\subsection{GLD calculations}

GLD is popular and user-friendly sizing software which is widely used in many commercial and residential ground loop applications. This is the reason for which it is selected to be compared with analytical correlations for borehole thermal resistance calculations. In the current work the Borehole Design Module especially the U-Tube panel is utilized. It contains [18] information related to the pipes and bore which are used to calculate the borehole thermal resistance according to Paul and Remund [23]. GLD calculates the convective resistance by Dittus-Boelter correlation [24] for turbulent flow in a circular tube with an average Reynolds number of 10000 and average values of viscosity and

Table 2. Thermal Conductivity of grout mixtures [18]

\begin{tabular}{|c|c|}
\hline Grouts & Thermal Conductivity (W/m K) \\
\hline \hline $20 \%$ Bentonite & 0.73 \\
\hline $30 \%$ Bentonite & 0.74 \\
\hline Cement Mortar & 0.78 \\
\hline Concrete $2100 \mathrm{~kg} / \mathrm{m}^{3}$ & 1.04 \\
\hline $30 \%$ Bentonite $-30 \%$ Quartzite & 1.3 \\
\hline $30 \%$ Bentonite - $40 \%$ Quartzite & 1.47 \\
\hline $60 \%$ Quartzite - Flowable Fill (Cement+Fly Ash+Sand) & 1.85 \\
\hline Concrete (50\% Quartz Sand) & 1.9 \\
\hline
\end{tabular}

Table 3. Coefficients of Eq. (4) [21]

\begin{tabular}{|c|c|c|}
\hline Configuration & $\boldsymbol{\beta}_{\mathbf{0}}$ & $\boldsymbol{\beta}_{\mathbf{i}}$ \\
\hline \hline Close Together & 20.10 & -0.9447 \\
\hline Average & 17.44 & -0.6052 \\
\hline Along Outer Wall & 21.91 & -0.3796 \\
\hline
\end{tabular}


the Prandtl number for water at $70{ }^{\circ} \mathrm{F}\left(21^{\circ} \mathrm{C}\right)$. An approximate value of pipe resistance for a HDPE pipe, with thermal conductivity of $0.23 \mathrm{Btu} /\left(\mathrm{hr} \mathrm{ft}^{\circ} \mathrm{F}\right)(0.40 \mathrm{~W} / \mathrm{m} \mathrm{K})$, is calculated using the expression for the hollow cylinder by Incropera and DeWitt [25]. It is worth mentioning that, in GLD, the close together configuration assumes an 1/8 in. $(3 \mathrm{~mm})$ average distance between the pipes and not touching one the other, an assumption which represents actual configurations in practice. Several calculations have been made for the pipe configurations, SDRs of the pipes, borehole diameters and grouts (see Table 2) which have been mentioned above.

\subsection{Numerical Simulation}

A 2-D steady-state finite element simulation is built up through Heat Transfer Module of COMSOL Multiphysics [26] in order to calculate borehole thermal resistances so as to be compared with those of Remund correlation [21] and to calculate total conductive heat fluxes. A square field, of 5.5 $\mathrm{m}$ edge, of four Borehole Heat Exchangers (BHEs), BHE1, BHE2, BHE3, BHE4 centered at its vertices, with a vertical U-tube GHE in each borehole has been placed at the infinite ground (see Fig. (2)). The square field selection is made so as to simulate a part of a real borehole field. The $5.5 \mathrm{~m}$ edge is also selected in order to ensure the absence of thermal interference between neighboring boreholes. An extra increase in edge size would not lead to significantly decrease in borehole thermal resistance while a decrease in edge size, especially below $5 \mathrm{~m}$, would lead to a portionally increase in borehole thermal resistance value in the region of $3 \%$ in the current work. It is also worth mentioning that in an actual borehole installation at which there are many vertical and horizontal series of boreholes, the $5.5 \mathrm{~m}$ distance between two successive boreholes does not eliminate thermal interference among them. In this case, longer distances are proposed if there is no space limit. A single U-tube GHE is placed in each borehole so as to be in accordance with the analytical and GLD analyses which are mentioned in sections 2.2 and 2.3.

The infinite ground is simulated as a circle with a radius of $20 \mathrm{~m}$, centered at the centre of the square field, with its circumference to be set to undisturbed ground temperature $\left(\mathrm{T}_{\mathrm{gr}}\right)$. Each bore has a diameter of $110 \mathrm{~mm}$, which is roughly in the middle of 90-190 mm range mentioned in section 2.1, and the pipes are sized according to SDR9, SDR11 and SDR17 with nominal diameter of 1 in $(25.4 \mathrm{~mm})$. It is obvious that the 20-meter radius is by far greater than the 55milimeter borehole radius so as the first can be characterized as satisfactory far away distance at which ground temperature is not affected by boreholes' presence. Only the circle's circumference is set to $T_{g r}$, enabling the temperature evolution to be developed during the simulation time from the boreholes' wall to thermally unaffected ground.

The GHE is modelled using a 2-D cross sectional area to its length at an average depth at which the ground temperature and the fluid temperatures in both the upward $\left(\mathrm{T}_{\mathrm{u}}\right)$ and

Table 4. COMSOL Modeling Parameters

\begin{tabular}{|c|c|}
\hline Parameter and Symbol & Value \\
\hline \multicolumn{2}{|l|}{ Infinite ground } \\
\hline Specific heat capacity $c_{\mathrm{p}, \mathrm{gr}}$ & $840 \mathrm{~J} / \mathrm{kg} \mathrm{K}$ \\
\hline Density $\rho_{\mathrm{gr}}$ & $2800 \mathrm{~kg} / \mathrm{m}^{3}$ \\
\hline Thermal conductivity $\mathrm{k}_{\mathrm{g}}$ & $0.78 \mathrm{~W} / \mathrm{m} \mathrm{K}$ \\
\hline Specific heat capacity $c_{p, g}$ & $1600 \mathrm{~J} / \mathrm{kg} \mathrm{K}$ \\
\hline Density $\rho_{g}$ & $1000 \mathrm{~kg} / \mathrm{m}^{3}$ \\
\hline \multicolumn{2}{|l|}{ HDPE } \\
\hline Density $\rho_{\mathrm{p}}$ & $940 \mathrm{~kg} / \mathrm{m}^{3}$ \\
\hline \multicolumn{2}{|l|}{ Operating conditions } \\
\hline Undisturbed ground temperature $\mathrm{T}_{\mathrm{gr}}$ & $18^{\circ} \mathrm{C}$ \\
\hline Temperature of upward flow in heating mode $T_{u, h}$ & $17^{\circ} \mathrm{C}$ \\
\hline Temperature of downward flow in heating mode $T_{\mathrm{d}, \mathrm{h}}$ & $14^{\circ} \mathrm{C}$ \\
\hline Temperature of upward flow in cooling mode $T_{u, c}$ & $30^{\circ} \mathrm{C}$ \\
\hline Temperature of downward flow in cooling mode $T_{d, c}$ & $33{ }^{\circ} \mathrm{C}$ \\
\hline
\end{tabular}


downward $\left(T_{d}\right)$ streams considered to have been stabilized in certain values. The governing heat transfer equation for conduction [24-27] is:

$\nabla\left(-k_{g} \nabla T\right)=Q+q_{s} T$

where $Q$ stands for heat sink or source and $q_{s}$ for the production or the absorption coefficient. In the current simulation $Q$ and $q_{s}$ are set to zero.

The modeling parameters are presented in the following Table 4. Ground, Grout and HDPE properties have been chosen so as to represent typical values for GHE simulations $[3,16]$. Ground thermal conductivity does not vary significantly among the tested rock types (that is $2.2-2.6 \mathrm{~W} / \mathrm{m} \mathrm{K}$ ) and heat capacity varies even less. As a result infinite ground parameters have negligible influence on total conductive heat flux and thus on borehole resistance calculation. Contrary to ground properties, grout properties, especially thermal conductivity, has great influence on total conductive heat flux and consequently on borehole thermal resistance. A grouting mixture with 'average' capacity to conduct heat $[3,16,18]$, that is grout of $0.78 \mathrm{~W} / \mathrm{m} \mathrm{K}$ thermal conductivity, is tested. The HDPE parameters have been justified in section 2.1.

A typical undisturbed temperature for Greek soils [28] at approximately $50 \mathrm{~m}$ depth is chosen and typical operating conditions with $\Delta \mathrm{T}=3{ }^{\circ} \mathrm{C}$ of the two streams in the GHE are assumed (Table 4). Three-degree temperature difference is the least permissible temperature difference between the two flow streams in the GHE so as to ensure its proper operation, while bigger temperature differences are desirable [3, 16, 29]. The temperatures of upward and downward stream in cooling mode have been selected according to Kavanaugh and Rafferty [29]. They suggest that the heat carrier fluid flowing through GHE should typically be between $5-11^{\circ} \mathrm{C}$ below the undisturbed ground temperature in heating mode and $11-17{ }^{\circ} \mathrm{C}$ above it in cooling one. However, in heating mode higher operating temperatures are assumed which usually appear in case of ground cooling depletion, after consecutive years of operation in higher cooling than heating loads. This fact is a common phenomenon in hot climates [30].

A triangular mesh, with increasing density in the borehole fields is applied. Several simulations are being performed using UMFPAK solver. The borehole resistance is calculated by Eq. (6) [31, 32]:

$$
R_{b}=\frac{T_{m}-T_{b}}{q}, T_{m}=\frac{T_{u}+T_{d}}{2}
$$

where $T_{b}$ is the borehole wall temperature and $q$ the algebraic sum of total heat flow of both pipes to the borehole circumference.

\section{RESULTS AND DISCUSSION}

Fig. (3) is created by computing borehole resistance values using Eq. (2), (3), (4) and GLD software for the three configurations of interest. It is worth mentioning that the borehole resistance calculated by Eq. (2) does not depend on the shank spacing between GHE pipes. The borehole resistance is plotted versus the dimensionless ratio of borehole diameter to outer pipe diameter which appears as an explicit factor in all equations.
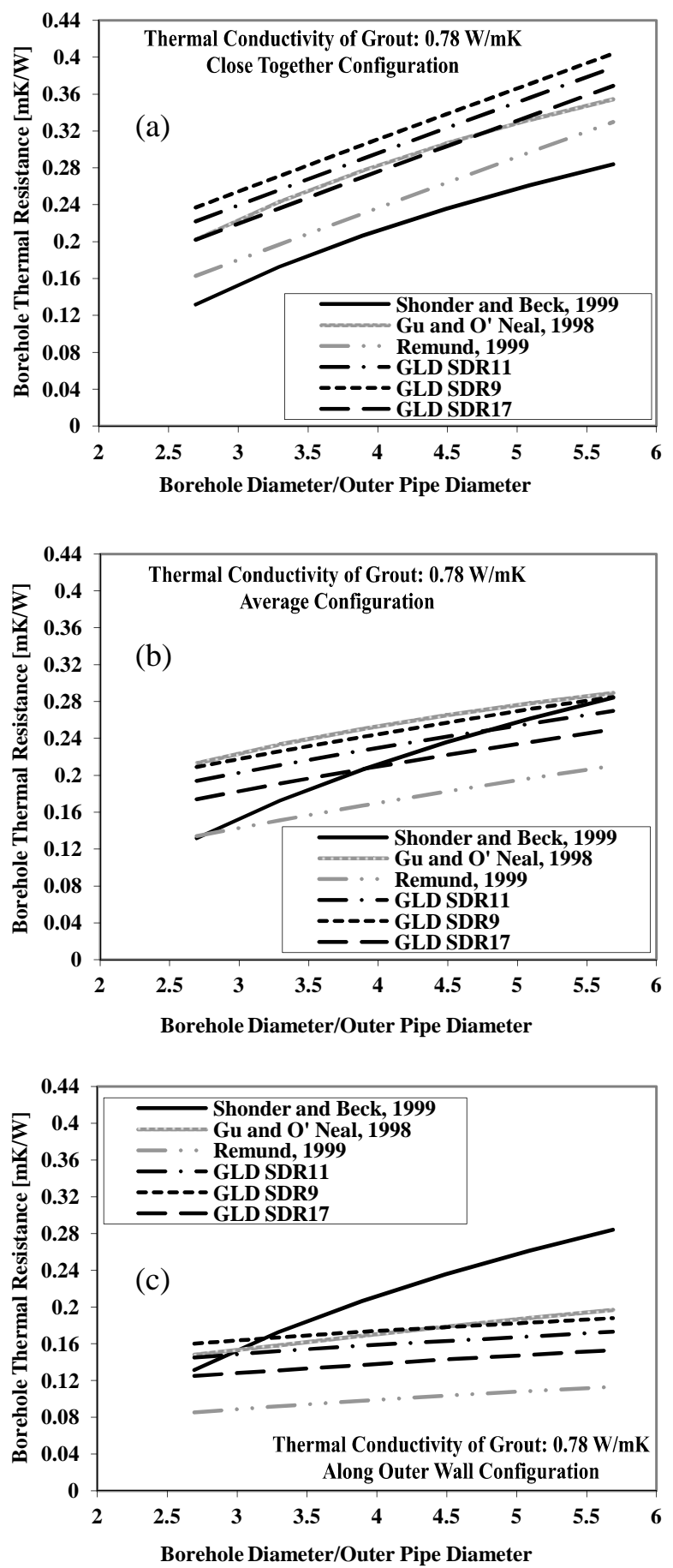

Fig. (3). Borehole thermal resistance versus dimensionless ratio of Borehole Diameter to Outer Pipe Diameter for (a) close together, (b) average and (c) along outer wall configuration.

It is obvious that GLD values are between the values calculated by analytical correlations except the ones referred to close together configuration, which are a little overestimated, perhaps due to the small gap between the legs of $U$ tube heat exchanger.

Fig. (4) depicts the variation of borehole thermal resistance due to different thermal conductivity of eight grouting 

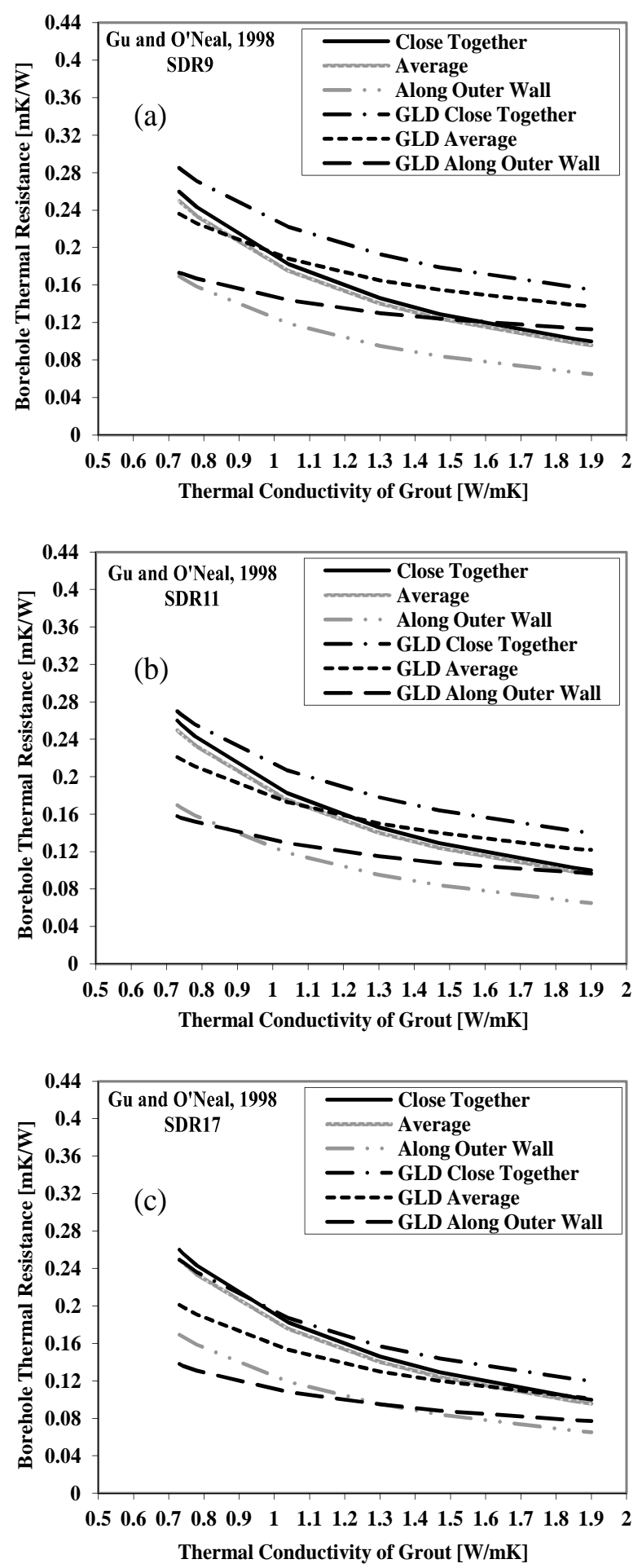

Fig. (4). Borehole thermal resistance versus thermal conductivity of grout for (a) SDR9, (b) SDR11, (c) SDR17.

mixtures (see Table 2) and SDRs (see Table 1) calculated by GLD in an acceptable accordance with Gu and O'Neal correlation (see Eq. (3)).

From the COMSOL modeling parameters, grout thermal conductivity has the greatest influence on the value of borehole thermal resistance. In the present numerical simulation, a grout of $0.78 \mathrm{~W} / \mathrm{m} \mathrm{K}$ thermal conductivity is selected to be used so as the calculated borehole thermal resistance to be compared with Remund analytical correlation outputs. Using grouts with higher thermal conductivity will decrease the borehole thermal resistance value in a similar way like in Fig. (4). The studied range of grout thermal conductivity value reaches $1.9 \mathrm{~W} / \mathrm{m} \mathrm{K}$, which shows the contemporary tendency to use thermally enhanced grouts (thermal conductivity in excess of $1.5 \mathrm{~W} / \mathrm{m} \mathrm{K}$ ). Considering higher undisturbed ground temperatures will decrease the total conductive heat flux during summer time while lower ground temperature will increase it. The opposite is expected during winter time. For constant summer conditions, by increasing the return (downward) stream temperature and consequently increasing the temperature difference between the flow streams in the GHE, an increase in total conductive heat flux will appear which will lead to a desired decrease in borehole thermal resistance. For constant winter conditions, by decreasing the return (downward) stream temperature and consequently increasing the temperature difference between the flow streams in the GHE, an increase in total conductive heat flux will appear which will lead to a desired decrease in borehole thermal resistance.

In Figs. (5) and (6) temperature profile in the borehole is presented for winter and summer working conditions, derived from COMSOL Multiphysics software.

Judging from the temperature distribution it is obvious that there is thermal interaction between the two flows in the Utube heat exchanger which affects the resistance being developed in the borehole and the total amount of heat flux exchanged per meter of length of GHE (see Table 5 for summer working conditions). This interaction is also affected from the pipe wall thickness.

In Fig. (7) borehole thermal resistance is plotted versus the dimensional ratio of shank spacing to borehole diameter for a grout of $0.78 \mathrm{~W} / \mathrm{m} \mathrm{K}$ thermal conductivity. As the shank spacing increases the borehole thermal resistance decreases, a remark which also accounts for the thermal interference between the two flow-streams in the borehole. Finally, in Fig. (8) borehole resistance for the three configurations is presented and compared with one derived from Eq. (4), for a grout of $0.78 \mathrm{~W} / \mathrm{m} \mathrm{K}$ thermal conductivity. Remund [21] estimation of borehole resistance is in satisfactory accordance with COMSOL computed values despite that it ignores the pipe resistance and takes into account only the grouting material and the shape factors. It is also useful to highlight that borehole resistance is the same for winter and summer working conditions of GHE for the simulation performed by COMSOL in the current paper.

\section{CONCLUSIONS}

Taking into consideration the borehole thermal resistance correlations mentioned above, three main conclusions have been derived. Firstly, the borehole thermal resistance decreases as shank spacing between GHE pipes increases. Secondly, a rise in grout's thermal conductivity leads to a fall of borehole resistance. Thirdly, the slighter wall pipe enables a bigger heat transfer rate between the heat carrier fluid and the ground. A small value of borehole thermal resistance is desirable in order to achieve a high performance of GHE, 


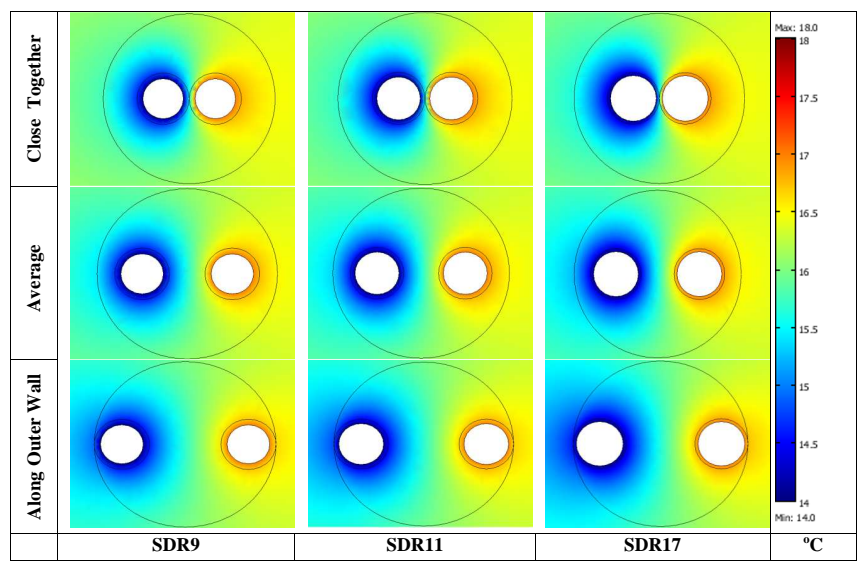

Fig. (5). Temperature distribution around a borehole for winter working conditions.

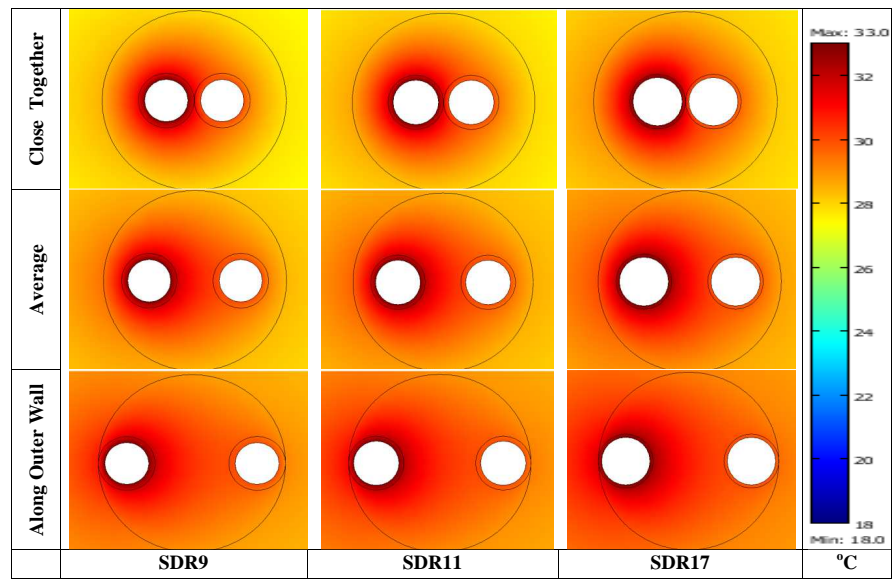

Fig. (6). Temperature distribution around a borehole for summer working conditions.

Table 5. Total Conductive Heat Flux for Summer Working Conditions

\begin{tabular}{|c|c|}
\hline Pipes' Dimensions and Configuration & Total conductive heat flux (W/m) \\
\hline \hline SDR9 & 16.14 \\
\hline Close Together & 17.17 \\
\hline Average & 18.24 \\
\hline Along Outer Wall & 16.41 \\
\hline SDR11 & 17.45 \\
\hline Close Together & 18.53 \\
\hline Average & 16.81 \\
\hline Along Outer Wall & 17.85 \\
\hline SDR17 & 18.99 \\
\hline Close Together & \\
\hline Average & \\
\hline Along Outer Wall & \\
\hline
\end{tabular}

meaning a high heat transfer rate. Based on this remark the thermally enhanced grouts tend to replace the common ones. The exact value of borehole resistance can be derived from experimental data of a specific GHE, although the existing correlation methods and software result at satisfactory estimations.

The current study is limited to steady-state analytical approaches and a 2-D steady-state numerical one. The use of 


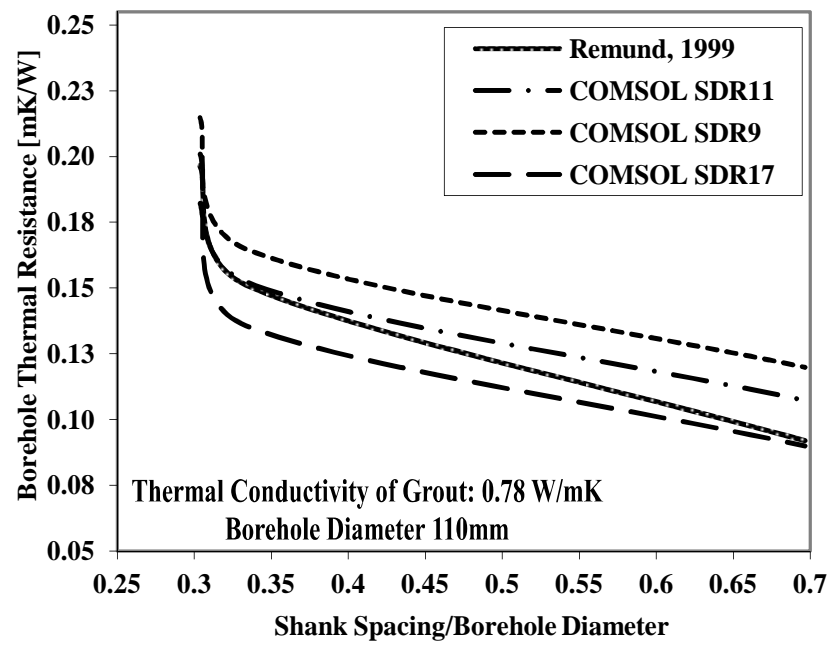

Fig. (7). Borehole thermal resistance as a function of Shank Spacing to Borehole Diameter for a grout of $0.78 \mathrm{~W} / \mathrm{m} \mathrm{K}$ thermal conductivity.

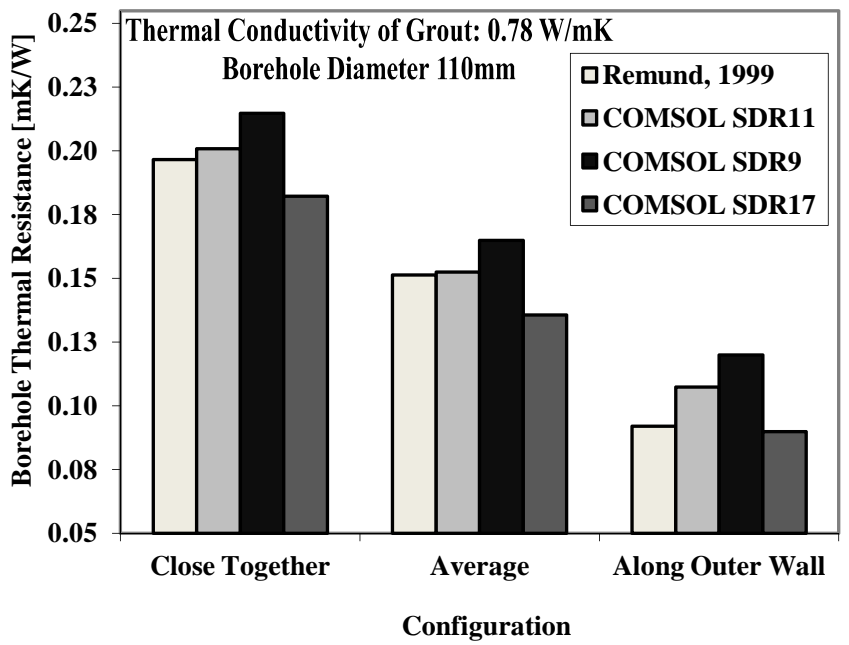

Fig. (8). Borehole thermal resistance for a grout of $0.78 \mathrm{~W} / \mathrm{m} \mathrm{K}$ thermal conductivity for three configurations.

transient analytical correlations in borehole thermal resistance calculations and the comparative study between transient and steady-state analysis with the use of the same dimensionless ratios (borehole diameter to outside pipe diameter, shank spacing to borehole diameter and SDR) are proposed for future research. What is more, 3-D steady-state or transient simulations can be attempted to calculate borehole thermal resistance values so as to be compared with the present study's results.

\section{CONFLICT OF INTEREST}

None declared.

\section{ACKNOWLEDGEMENTS}

None declared.

\section{NOMENCLATURE}

$d_{b} \quad=\quad$ Borehole diameter $(\mathrm{mm})$

$\begin{array}{lll}d_{i}, d_{o} & = & \text { Pipe inner, outer diameter }(\mathrm{mm}) \\ n & = & \text { Number of pipes in the borehole } \\ Q & = & \text { Heat sink or source }(\mathrm{W} / \mathrm{m} \mathrm{K}) \\ q & = & \begin{array}{l}\text { Algebraic sum of total heat flow of pipes } \\ (\mathrm{W} / \mathrm{m})\end{array} \\ q_{s} & =\quad \begin{array}{l}\text { Production or absorption coefficient } \\ \left(\mathrm{W} / \mathrm{m}^{3} \mathrm{~K}\right)\end{array} \\ R_{b} & =\quad \text { Borehole thermal resistance }(\mathrm{m} \mathrm{K} / \mathrm{W}) \\ s & = & \text { Shank spacing }(\mathrm{mm}) \\ s_{p} & = & \text { Pipe wall thickness }(\mathrm{mm}) \\ T_{b} & = & \text { Borehole wall temperature }\left({ }^{\circ} \mathrm{C}\right) \\ T_{d}, & = & \text { Downward } \\ T_{u} & = & \text { Upward flow stream temperature }\left({ }^{\circ} \mathrm{C}\right) \\ T_{g r} & = & \text { Undisturbed ground temperature }\left({ }^{\circ} \mathrm{C}\right) \\ \beta_{o}, \beta_{i} & = & \text { Coefficient of Eq. }(4)\end{array}$

\section{ABBREVIATIONS}

$\begin{array}{lll}\text { GSHP } & =\text { Ground Source Heat Pump } \\ \text { GHE } & =\text { Ground Heat Exchanger } \\ \text { 1,2,3-D } & =\text { One, Two, Three-Dimensional } \\ \text { SDR } & =\text { Standard Dimension Ratio } \\ \text { HDPE } & =\text { High Density Polyethylene } \\ \text { GLD } & =\text { Ground Loop Design } \\ \text { BHEs } & =\text { Borehole Heat Exchangers }\end{array}$

\section{REFERENCES}

[1] Ozgener, L.; Hepbasli, A.; Dincer, I.; Rosen, A.M. Exergoeconomic analysis of geothermal district heating systems: A case study. Appl. Thermal Eng., 2007, 27, 1303-1310.

[2] Akella, K.A.; Saini, P.R.; Sharma, P.M. Social, economical and environmental impacts of renewable energy systems. Renewable Energy, 2009, 34, 390-396.

[3] Chua, K.J.; Chou, S.K.; Yang, W.M. Advances in heat pump systems: A review. Appl. Energy, 2010, 87, 3611-3624.

[4] Connolly, D.; Lund, H.; Mathiesen, B.V.; Leahy, M. A review of computer tools for analysing the integration of renewable energy into various energy systems. Appl. Energy, 2010, 87, 1059-1082.

[5] Cheng, C.T.; Ou, C.P.; Chau, K.W. Combining a fuzzy optimal model with a genetic algorithm to solve multi-objective rainfallrunoff model calibration. J. Hydrol., 2002, 268, 72-86.

[6] Muttil, N.; Chau, K.W. Neural network and genetic programming for modelling coastal algal blooms. Int. J. Environ. Pollut., 2006, $28,223-238$.

[7] Ingersoll, L.R.; Zobel, O.J.; Ingersoll, A.C. Heat Conduction with Engineering and Geological Application; McGraw Hill: New York, 1948.

[8] Carslaw, H.S.; Jaeger, J.C. Conduction of Heat in Solids, 2nd ed.; Oxford University Press: London, 1959.

[9] Ingersoll, L.R.; Zobel, O.J.; Ingersoll, A.C. Heat Conduction with Engineering, Geological and Other Applications, revised edition; University of Wisconsin Press: Madison, 1954.

[10] Deerman, J. D.; Kavanaugh, S.P. Simulation of vertical U-tube ground coupled heat pump systems using the cylindrical heat source solution. ASHRAE Trans., 1991, 97, 287-295.

[11] Rottmayer, S.P. M.Sc. Thesis, University of Wisconsin, 1997.

[12] Florides, G.; Kalogirou, S. Ground heat exchangers - a review of systems, models and applications. Renewable Energy, 2007, 32, 2461-2478. 
[13] Signorelli, S.; Kohl, T.; Rybach, L. Sustainability of Production from Borehole Heat Exchanger Fields, Proceedings of World Geothermal Congress 2005, Antalya, Turkey, April 24-29, 2005.

[14] Shonder, J.A.; Beck, J.V. Determining effective soil formation thermal properties from field data using a parameter estimation technique. ASHRAE Trans. 1999, 105, 458-466.

[15] Yavuzturk, C.; Spitler, J.D.; Rees, S.J. A transient two-dimensional finite volume model for the simulation of vertical U-tube ground heat exchangers. ASHRAE Trans. 1999, 105, 465-474.

[16] Banks, D. An Introduction to Thermogeology: Ground Source Heating and Cooling, Blackwell Publishing, 2008.

[17] Engineering Toolbox. http://www.engineeringtoolbox.com (accessed November 8, 2010).

[18] Gaia Geothermal. Ground Loop Design Software, GLD 2009

[19] Shonder, J.A.; Beck, J.V. Field test of a new method for determining soil formation thermal conductivity and borehole resistance. ASHRAE Trans. 2000, 106, 843-850.

[20] Gu, Y.; O’Neal, D.L. Development of an equivalent diameter expression for vertical U-tubes used in ground-coupled heat pumps. ASHRAE Trans, 1998, 104, 347-355.

[21] Remund, C.P. Borehole thermal resistance: laboratory and field studies. ASHRAE Trans. 1999, 105, 439-445.

[22] Bose, J.E.; Parker, J.D.; McQuiston, F.C. Design/Data Manual for Closed-Loop Ground-Coupled Heat Pump Systems; American Society of Heating, Refrigeration and Air Conditioning Engineers (ASHRAE): Atlanta, 1985.
[23] Remund, C.P.; Paul, N.D. A Nationally Acceptable Grouting Manual for GSHP Boreholes, Draft; Electric Power Research Institute, RP-3881-1: Palo Alto, 1996.

[24] Holman, J.P. Heat Transfer, $9^{\text {th }}$ ed; McGraw Hill Companies Inc.: New York, 2002.

[25] Incropera, F.P.; Dewitt, D.P. Fundamentals of Heat and Mass Transfer, 5th ed.; John Wiley \& Sons Inc.: New York, 2002.

[26] COMSOL Multiphysics, v. 4.0; Heat Transfer Module, 2010

[27] Rakopoulos, C.D. Heat \& Mass Transfer II; Frame Publishing Co.: Athens, 1985.

[28] Katsoyiannis, I.A.; Hug, S.J.; Ammann, A.; Zikoudi, A; Hatziliontos, C. Arsenic speciation and uranium concentrations in drinking water supply wells in Northern Greece: Correlations with redox indicative parameters and implications for groundwater treatment. Sci Total Environ. 2007, 383, 128-140.

[29] Kavanaugh, S.P.; Rafferty, K. Design of Geothermal Systems for Commercial and Institutional Buildings; American Society of Heating, Refrigeration and Air Conditioning Engineers (ASHRAE), 1997.

[30] Esen, H.; Inalli, M.; Esen, Y. Temperature distributions in boreholes of a vertical ground-coupled heat pump system. Renewable Energy, 2009, 34, 2672-2679.

[31] Eskilson, P.; Claesson, J. Simulation model for thermally interacting heat extraction boreholes. Numer. Heat Transfer, 1988, 13, $149-165$.

[32] Acuña, J.; Palm, B. Local Conduction Heat Transfer in U-pipe Borehole Heat Exchangers, Excerpt from the Proceedings of the COMSOL Conference 2009, Milan, Italy, October 14-16, -

(C) Sagia et al.; Licensee Bentham Open.

This is an open access article licensed under the terms of the Creative Commons Attribution Non-Commercial License (http://creativecommons.org/licenses/by-nc/3.0/) which permits unrestricted, non-commercial use, distribution and reproduction in any medium, provided the work is properly cited. 